\title{
Small scale production of recombinant adeno-associated viral vectors for gene delivery to the nervous system
}

Running title: Small scale production of rAAV vectors

Joost Verhaagen ${ }^{1 *}$, Barbara Hobo ${ }^{1}$, Erich M.E. Ehlert ${ }^{1,2}$, Ruben Eggers ${ }^{1}$, Joanna A. Korecka ${ }^{1,3}$, Stefan A. Hoyng ${ }^{1,4}$, Callan L. Attwell ${ }^{1}$, Alan R. Harvey, ${ }^{5,6}$, Matthew R.J. Mason ${ }^{1}$

${ }^{1}$ Netherlands Institute for Neurosciences, Meibergdreef 47, 1105BA Amsterdam, The Netherlands

${ }^{2}$ Current address: uniQure, Meibergdreef 61, 1105BA Amsterdam, The Netherlands

${ }^{3}$ Current address: Neuroregeneration Research Institute, McLean Hospital/Harvard Medical School, 115 Mill Street, Belmont, MA 02478, USA

${ }^{4}$ Department of Neurosurgery, Leiden University Medical Center, Albinusdreef 2, 2333ZA Leiden, The Netherlands

${ }^{5}$ School of Anatomy, Physiology and Human Biology, The University of Western Australia, Crawley, WA, Australia

${ }^{6}$ Perron institute for Neurological and Translational Science, WA, Australia

*Corresponding author: Joost Verhaagen, j.verhaagen@nin.knaw.nl 


\section{Abstract}

Adeno-associated viral vectors have numerous applications in neuroscience, including the study of gene function in health and disease, targeting of light-sensitive proteins to anatomically distinct sets of neurons to manipulate neuronal activity (optogenetics), and the delivery of fluorescent protein to study anatomical connectivity in the brain. Moreover several phase I/II clinical trials for gene therapy of eye and brain diseases with adenoassociated viral vectors have shown that these vectors are well-tolerated by human patients. In this article we describe a detailed protocol for the small scale production of recombinant adeno-associated viral vectors. This protocol can be executed by investigators with experience in cell culture and molecular biological techniques in any well-equipped molecular neurobiology laboratory. With this protocol we typically obtain research batches of $100-200 \mu \mathrm{L}$ that range in titer from $5 \times 10^{12}$ to $2 \times 10^{13}$ genomic copies $/ \mathrm{mL}$.

\section{Key words}

Adeno-associated viral vector, production, purification, serotype, iodixanol, Amicon centrifugation device

\section{Introduction}

Adeno-associated virus (AAV) is a non-pathogenic parvovirus belonging to the subfamily of dependoviruses. Dependoviruses cannot replicate autonomously but need a helper virus for their propagation. Adenovirus or herpesvirus can serve as helper virus for AAV. AAV is therefore a "replication defective" virus by nature. The genome of AAV consists of three 
open reading frames encoding the rep and cap proteins and the assembly activator protein, flanked by inverted terminal repeats (ITRs). The cap genes encode the capsid proteins and the rep genes are required for DNA replication which only occurs in the presence of additional helper functions provided by the helper virus ${ }^{1}$.

Over the last three decades protocols have been developed to generate and purify high titer stocks of recombinant adeno-associated viral vectors (rAAV). In early methods to produce rAAV an adenovirus was required as helper virus. As a result, batches of rAAV were contaminated with adenovirus. The identification of the adenoviral genes required for the propagation of rAAV vectors has allowed the creation of a rAAV production system that is entirely plasmid based ${ }^{2-5}$. Today the nine most commonly used rAAV serotypes are produced by dual or triple plasmid transfections in human embryonic kidney (HEK) 293T cells. In the dual plasmid production system the transfer plasmid contains the gene of interest under the control of a promoter flanked by the ITRs from AAV2 and the helper plasmid harbors the AAV2 rep genes, the cap genes of a specific AAV serotype and the adenoviral helper functions ${ }^{3}$. In the triple plasmid production system the rep and cap genes and the adenoviral helper functions resent on two different plasmids ${ }^{6}$. Thus, for each rAAV serotype the helper plasmid harbors the specific cap genes of the desired serotype. Serotypes 1 to 6 are produced through the dual plasmid system and serotypes 7 to 9 by means of the triple plasmid system. Large scale production protocols for rAAV in either insect cell $s^{7,8}$ or mammalian cells ${ }^{9}$ have also been developed. These production systems are mainly used to generate large amounts of rAAV for preclinical or clinical studies.

In this article a simple four stage production protocol is provided for the generation of relatively small quantities (100-200 $\mu$ l) of rAAV with a titer typically ranging between $1 \mathrm{x}$ 
$10^{12}$ to $2 \times 10^{13}$ genomic copies $/ \mathrm{mL}$. The first stage involves the production of rAAV by cotransfection of two or three plasmids (the transfer plasmids mixed with one or two helper plasmids depending on the rAAV serotype) in HEK293T cells. In the second stage rAAV is collected from the transfected cells and concentrated by iodixanol gradient ultracentrifugation. Thirdly, rAAV from the iodixanol gradient is concentrated and separated from cellular proteins by multiple washes and centrifugation in Amicon centrifugal filter devices. Fourth, the titer of the rAAV sample is determined by quantitative PCR (qPCR) on rAAV genomic DNA. This protocol is a modification and extension of original protocols developed earlier and can be completed in 7 to 8 working days $4,5,10,11$. Finally, we describe our method to deliver rAAV to the brain ${ }^{12-15}$ and to the retina by intravitreal injection ${ }^{16,17}$.

\section{Materials}

2.1. Reagents for cell culture and PEI-mediated plasmid transfection

1. DMEM: Dulbecco's Modified Earl's medium supplemented with $10 \%$ fetal calf serum (FCS) and $1 \% \mathrm{v} / \mathrm{v}$ penicillin/streptomycin (PS)

2. IMDM: Iscoves Modified Dulbecco's medium supplemented with $10 \% \mathrm{FCS} / 1 \% \mathrm{v} / \mathrm{v}$ $\mathrm{PS} / 1 \% \mathrm{v} / \mathrm{v}$ glutamine (GLN).

3. PEI solution: add $500 \mathrm{mg}$ Polyethylenimine (PEI, $25 \mathrm{kD}$, linear, powder) to $450 \mathrm{~mL} \mathrm{H}_{2} \mathrm{O}$ and lower the $\mathrm{pH}$ to 2.0 with $12 \mathrm{~N} \mathrm{HCl}$ to dissolve the PEl. Adjust the $\mathrm{pH}$ with $10 \mathrm{M}$ $\mathrm{NaOH}$ to 7.0. Adjust the volume to $500 \mathrm{~mL}$ yielding a PEl solution of $1 \mathrm{mg} / \mathrm{mL}$. The solution is stored in frozen aliquots after sterilization through a $0.2 \mu \mathrm{m}$ filter.

4. HEK293T cells: Human embryonic kidney-derived 293T cells

5. Plasmids: helper plasmids required for each serotype are specified in Table 1. 
6. $15 \mathrm{~cm}$ tissue culture plate

[Table 1 near here]

2.2. Reagents for rAAV harvest and lodixanol gradient centrifugation

1. Iodixanol: start with a $60 \%$ solution to generate the 15,25 and $40 \%$ solutions as follows:

$15 \%$ iodixanol: dilute $60 \mathrm{~mL} 60 \%$ lodixanol with $48 \mathrm{~mL} 5 \mathrm{M} \mathrm{NaCl}$ and $48 \mathrm{~mL} 5 x$ PBSMK (5x PBS with $5 \mathrm{mM} \mathrm{MgCl}_{2}$ and $12.5 \mathrm{mM} \mathrm{KCl}$ ), add water to a volume of $240 \mathrm{~mL}$. $25 \%$ iodixanol, dilute $67 \mathrm{~mL} 60 \%$ lodixanol with $32 \mathrm{~mL} 5 \times$ PBS-MK, add water to a volume of $160 \mathrm{~mL}$.

$40 \%$ iodixanol, dilute $160 \mathrm{~mL} 60 \%$ lodixanol with $48 \mathrm{~mL} 5 \times$ PBS-MK, add water to a volume of $240 \mathrm{~mL}$.

2. DNasel: $10 \mathrm{mg}$ DNasel/mL PBS

3. D-PBS: Dulbecco's phosphate buffered saline (Gibco)

4. Alternative lysis buffer: $50 \mathrm{mM}$ Tris pH 8.5, $150 \mathrm{mM} \mathrm{NaCl}, 0.1 \%$ Triton X-100, $2 \mathrm{mM}$ $\mathrm{MgCl}_{2}$

2.3. Reagents for Amicon filter centrifugation concentration

1. D-PBS

2. D-PBS with $5 \%$ sucrose: $5 \mathrm{~g}$ sucrose in $100 \mathrm{~mL} \mathrm{D-PBS}$, store aliquots at $-20^{\circ} \mathrm{C}$ 
2.4 Reagents for rAAV titering

1. Titration DNasel solution: $250 \mu \mathrm{g} / \mathrm{mL}$ DNAase I in D-PBS supplemented with $3 \mathrm{mM}$ $\mathrm{MgCl}_{2}$

2. $1 \mathrm{M} \mathrm{NaOH}$ for alkaline lysis

3. Neutralization solution: mix 1 part $1 \mathrm{M}$ Tris $\mathrm{pH} 8$ and 4 parts $1.25 \mathrm{M} \mathrm{HCl}$

4. Master mix: SYBRgreen solution (Applied Biosystems).

5. Primers: designed against your sequence of interest (see Note 1)

6. qPCR plate (MicroAmp optical 96 well reaction plate)

7. PCR thermocycler with heated lid

2.5 Specialist devices and equipment for rAAV production

1. Cell Scraper with a length of $28 \mathrm{~cm}$ (Greiner Bio-One)

2. Amicon ultra-15 centrifugal filters 100k (Merck Millipore UFC910024)

3. Vortex

4. Ultracentrifuge: a Beckman L-80 ultracentrifuge or equivalent ultracentrifuge

5. Table-top centrifuge with inserts for $50 \mathrm{~mL}$ tubes e.g. Eppendorf $5810 \mathrm{R}$ centrifuge, and inserts for qPCR plates

6. 70Ti Beckman rotor

7. PCR system with heated lid e.g. Biorad T100

8. qPCR system e.g. a 7300 real time PCR system of Applied Biosystems

9. 19G needle 
10. $30 \mathrm{G}$ needle

11. Pasteur pipette

12. Ultracentrifuge Quick-Seal polypropylene tube (Beckman)

13. Biohazard hood

14. Metal clamp

15. Latex or nitrile gloves

16. Screw-top $1.5 \mathrm{~mL}$ tube

17. Serological pipettes

2.6 Equipment and reagents for delivery of rAAV to the brain and retina

1. Sterilized surgical equipment, including a scalpel handle, forceps, fine scissors (fine science tools), a dental drill, cotton swabs, eye ointment, and different size sutures.

2. $50 \mu \mathrm{L}$ Hamilton for injection of $A A V$ into the vitreal chamber of the eye

3. Automated microinjection device; Harvard apparatus or Nanojet

3. Stereotactic apparatus (Kopf)

4. Custom pulled glass capillaries $1.5 \mathrm{~mm}$ OD x $0.86 \mathrm{~mm}$ ID (\#30-0053, Harvard apparatus) with an $80 \mu \mathrm{m}$ tip diameter.

5. Polyethylene tubing $0.61 \mathrm{~mm}$ OD $\times 0.28 \mathrm{~mm}$ ID (\#800/100/100 Portex, Smiths medical)

6. Two component epoxy resin (combi rapide, Bison)

7. Mineral oil when using a glass micropipette attached to a Hamilton syringe via polyethylene tubing

8. Heating pad 
9. Isoflurane equipment, lidocaine (local anaesthetics), Sterile water (fill needle system), Fynadine ( $2.5 \mathrm{mg} / \mathrm{kg}$ s.c. flunixin)

10. Inhalation anesthesia using a mixture of $(0.2 \mathrm{~L} / \mathrm{min}) \mathrm{O}_{2}$ and $(0.4 \mathrm{~L} / \mathrm{min})$ medicinal air containing $1.6 \%$ isoflurane

11. $70 \%$ ethanol

12. PTFE Luer Lock and a cannula with appropriate size to fit the inner diameter of the polyethylene tubing

\section{Methods}

\subsection{Cell culture and PEI-transfection}

Day 1.

1. Plate 1 to $1,25 \times 10^{7}$ HEK293T cells (passage number not higher than 20 ) per $15 \mathrm{~cm}$ tissue culture plate in DMEM in a tissue culture incubator at $37^{\circ} \mathrm{C}$ and in $5 \% \mathrm{CO}_{2}$. Prepare 8 plates for a typical batch of rAAV (see Note 2).

Day 2.

2. Check HEK293T cells around 3 PM. The cells should have grown to 70 to $80 \%$ confluency. The transfection efficiency drops significantly when cells are too confluent.

3. Pre-warm IMDM in a water bath to $37^{\circ} \mathrm{C}$. Per $15 \mathrm{~cm}$ plate you will need $20 \mathrm{~mL}$ of IMDM.

4. Replace DMEM with IMDM two hours before the transfection. 
5. Thaw the PEl solution (A) and prepare the plasmid solution (B) for transfection according to Table 2. For AAV 1 to 6 a two plasmid system is used. For AAV 7 to 9 a three plasmid system is used (Table 1).

6. Mix A and B (1:1) and vortex immediately. Incubate for 15 minutes at RT.

7. Add the mixture to the HEK293T cells in IMDM. Per plate add $2 \mathrm{~mL}$ of solution in a dropwise fashion. Ensure that the solution is equally distributed over the cells.

8. The plates are returned to the tissue culture incubator and transfected cell are cultured until the next morning (16 - 18 hours after the transfection).

[Table 2 near here]

Day 3.

9. Prewarm IMDM in a water bath to $37^{\circ} \mathrm{C}$.

10. Replace IMDM with fresh IMDM, $20 \mathrm{~mL}$ per plate. Process one plate at a time to prevent cells from drying out.

11. If the transfer plasmid contains a fluorophore (e.g. GFP) it is possible to check the transfection efficiency under an inverse fluorescence microscope. At this point in time around $30 \%$ of the cells should express detectable GFP.

Day 4.

12. Check the condition of the cells under the inverse microscope. Cells should appear viable and the proportion of transfected cells has increased to approximately 60 to $80 \%$ (see Note 3 ). For rAAV serotypes 1 to 6,8 and 9 rAAV is 
harvested on day 5. However, for AAV7 we consistently observed that the transfected cells start to detach from the cell culture dish on day 5 and with this serotype we therefore start the rAAV harvest on day 4.

\subsection{Harvest of rAAV and iodixanol gradient ultracentrifugation}

Day 5.

1. Aspirate medium from the cell culture plates. Two plates at a time.

2. Add $3 \mathrm{~mL}$ D-PBS to the first plate. Scape the cells from the first plate with a cell scraper. Aspirate the harvested cells and add this mixture to the second medium free plate and remove the cells by cell scraping. Collect the cell mixture in a 50 $\mathrm{mL}$ tube. Repeat this until cells from all plates have been harvested. Total volume of the cell harvest of 8 plates should not exceed $17,5 \mathrm{~mL}$ because otherwise it cannot be applied on the iodixanol gradient.

3. Freeze/thaw cells three times by freezing in dry ice-cooled ethanol and thawing in a $37^{\circ} \mathrm{C}$ water bath until completely thawed.

4. After each freeze/thaw cycle check for large cell clumps in the solution. If these occur vortex the solution to break up cells clumps.

5. Alternative method: Scrape in alternative lysis buffer. Use $16 \mathrm{~mL}$ total. This is quicker for harvesting but the detergent can cause bubble formation during the iodixanol gradient step.

6. Add $25 \mu \mathrm{L}$ DNAsel, incubate for 1 hour at $37^{\circ} \mathrm{C}$ in a water bath. (see Note 4 )

7. Store the cell lysate at $-20^{\circ} \mathrm{C}$. Continue with the iodixanol density ultracentrifugation the next day. 


\subsection{Iodixanol gradient centrifugation}

Day 6 .

1. Defrost the cell lysate in a $37^{\circ} \mathrm{C}$ water bath.

2. Centrifuge lysate for $30 \mathrm{~min}$ at $3220 \mathrm{xg}$ in a table centrifuge.

3. Apply a maximum of $17,5 \mathrm{~mL}$ of cell lysate to the bottom of a Beckman ultracentrifuge Quick-Seal polypropylene tube with a Pasteur pipet (see Note 5).

4. Replace the Pasteur pipette with a new one. This pipette will be used to underlayer the iodixanol gradient solutions (Figure 1).

5. Gently infuse $9 \mathrm{~mL}$ of the $15 \%$ iodixanol solution under the cell lysate and continue with $5 \mathrm{~mL}$ of the $25 \%$ and $40 \%$ iodixanol solution and finally $3 \mathrm{~mL}$ of the $60 \%$ iodixanol solution (Figure 1 ; see Note $\mathbf{6}^{11}$ ).

6. Fill the tube with D-PBS to the bottom of the neck (but not into the neck) to remove any remaining air bubbles. A $1 \mathrm{~mL}$ syringe with a $19 \mathrm{G}$ needle can be used for this (see Note 7).

7. Seal the tube using the electrical tube topper. Ensure that the neck of the Beckman tube is dry because the tube will not seal properly if the neck is wet. Carefully squeeze the sealed Beckman tube to make sure that the tube is indeed fully sealed and not leaking.

8. Centrifuge in Beckman centrifuge in a 70Ti fixed angle rotor for 70 minutes at $69.000 \mathrm{rpm}$ at $16^{\circ} \mathrm{C}$.

9. After centrifugation open the rotor in the biohazard hood and assemble the first Beckman tube in a metal clamp (see Note 8). 
10. Puncture a small hole in the top of the tube with a $30 \mathrm{G}$ needle. Leave the needle in place.

11. Puncture a hole in the bottom of the tube with a 19G needle. First gently remove the $19 \mathrm{G}$ needle, subsequently remove the $30 \mathrm{G}$ needle and close the hole with your gloved finger. To collect the iodixanol fractions in steps 12 and 13 slowly allow air into the centrifuge tube via the hole punctured with the top $30 \mathrm{G}$ needle.

12. Collect the first $2 \mathrm{~mL}$ of iodixanol (60\% iodixanol) in a $15 \mathrm{~mL}$ tube and discard.

13. Collect the next $3 \mathrm{~mL}$ of iodixanol ( $1 \mathrm{~mL}$ of $60 \%$ and $2 \mathrm{~mL}$ of $40 \%$ iodixanol). This fraction contains your rAAV.

[Figure 1 near here]

\subsection{Amicon filter centrifugation of rAAV, washing and concentration}

1. Dilute the $3 \mathrm{~mL}$ iodixanol solution that contains the rAAV (step 3.3.13) with $12 \mathrm{~mL}$ D-PBS. Mix well.

2. Apply this solution to an Amicon ultra 15 device.

3. Concentrate by centrifugation at $3220 \times \mathrm{g}$ for 15 minutes at RT to reduce the volume to approximately $500 \mu \mathrm{L}$. Additional centrifuging time may be necessary.

4. Discard the flow through.

5. Add $15 \mathrm{~mL}$ of D-PBS plus $5 \%$ sucrose to the concentrated rAAV solution.

6. Centrifuge at $3220 \times \mathrm{g}$ for 10 minutes at RT to approximately $500 \mu \mathrm{L}$.

7. Repeat this at least three times (see Note 9). 
8. In the last Amicon wash and concentration step centrifuge until the volume of your rAAV solution is between 150 and $200 \mu \mathrm{L}$. Additional centrifuging may be necessary to reduce the volume to this.

9. Transfer your rAAV to a screw-top $1.5 \mathrm{~mL}$ tube and store at $-80^{\circ} \mathrm{C}$ (see Note 10 ).

\section{5 rAAV titration}

Day 7.

1. Add $2,2 \mu \mathrm{l}$ of rAAV stock to $85,8 \mu \mathrm{L}$ of Titration DNAsel solution. Mix well by pipetting and divide in two aliquots of $40 \mu \mathrm{l}$ in PCR tubes (this is a 1:40 dilution)

2. If necessary spin the samples a few second at $200 \times \mathrm{g}$ in the micro centrifuge to collect the sample at the bottom of the tube.

3. Incubate 30 minutes at $37^{\circ} \mathrm{C}$ in the PCR thermocycler with heated lid.

4. Incubate 3 minutes at $12^{\circ} \mathrm{C}$ in the PCR thermocycler with heated lid.

5. Spin down for a few second at $200 \times \mathrm{g}$ in the table centrifuge to collect the sample at the bottom of the tube.

6. Add $40 \mu \mathrm{L}$ of $1 \mathrm{M} \mathrm{NaOH}$ and vortex briefly (see Note 11).

7. Spin the samples a few second at $200 \times \mathrm{g}$ in a table-top centrifuge to collect the sample at the bottom of the tube.

8. Incubate 15 minutes at $50^{\circ} \mathrm{C}$ in the PCR thermocycler with heated lid.

9. Add around $40 \mu \mathrm{l}$ neutralization solution (exact volume determined previously, see Note 11) to each sample. Vortex and spin down at $200 \times \mathrm{g}$.

10. From each sample take $20 \mu \mathrm{L}$ and dilute in $180 \mu \mathrm{L} \mathrm{H}_{2} \mathrm{O}$ (1: 10 dilution). Keep the samples on ice and continue with step 11 or freeze at $-20^{\circ} \mathrm{C}$ and continue later. 
11. Prepare a standard curve for the qPCR using a reference plasmid.

12. First make a solution of $10^{10}$ molecules $/ \mathrm{mL}$. For example, using pTR-CGW (FW $3496 \mathrm{kD})$, this is $58.4 \mathrm{pg} / \mu \mathrm{L} .16 .7 \mu \mathrm{L}$ of pTR-CGW $(1 \mu \mathrm{g} / \mu \mathrm{L})$ is diluted in $5 \mathrm{~mL} \mathrm{H} \mathrm{H}_{2} \mathrm{O}$ resulting in a $4 \mathrm{ng} / \mu \mathrm{L}$ stock solution. $5895 \mu \mathrm{L}$ of $\mathrm{H}_{2} \mathrm{O}$ is added to $105 \mu \mathrm{l}$ of the $4 \mathrm{ng} / \mu \mathrm{L}$ stock giving $58.4 \mathrm{pg} / \mu \mathrm{L}$, or $10^{10}$ plasmid molecules per $\mathrm{mL}$. Make 1:10 serial dilutions to a final dilution of $10^{3}$ plasmid molecules per $\mathrm{mL}$. These serial dilutions can be stored and used for a number of standard curves in the future. Vortex thoroughly before each use.

13. Prepare reaction mix for the $\mathrm{qPCR}$ in $\mathrm{qPCR}$ plate. Total volume per reaction is 25 $\mu$ l. For each reaction: $12,5 \mu \mathrm{l}$ SYBRgreen master mix, $0,75 \mu$ l primer mix (10 $\mu \mathrm{M}$ of forward and reverse primer, see Note 1), $10 \mu \mathrm{l}$ rAAV DNA (step 11) or $10 \mu \mathrm{l}$ from the serial dilutions of the standard curve, and finally $1,75 \mu \mathrm{l} \mathrm{H}_{2} \mathrm{O}$. Spin the qPCR plate at $200 \mathrm{xg}$ for a few second.

14. Place qPCR plate in the qPCR machine and start the cycling: First cycle: 2 minutes $50^{\circ} \mathrm{C}, 10$ minutes $95^{\circ} \mathrm{C} ; 40$ cycles: 15 seconds $95^{\circ} \mathrm{C}, 1$ minute $60^{\circ} \mathrm{C}$; Dissociation stage: 15 seconds $95^{\circ} \mathrm{C}, 1$ minute $60^{\circ} \mathrm{C}, 15$ seconds $95^{\circ} \mathrm{C}, 15$ seconds $60^{\circ} \mathrm{C}$, cool down to RT.

15. Calculate titers from the cycle threshold values using the standard curve, taking into account the dilution steps in the procedure (an initial 1:40 dilution, the 1:3 dilution during alkaline lysis and neutralization and the last 1:10 dilution, giving a final dilution of 1:1200).

3.6 Stereotactic delivery of rAAV to the brain (in some jurisdictions this procedure needs to be performed in a suitable biosafety cabinet) 
1. Tubing is connected to the glass needle by application of the two component resin. The opposite side is mounted onto the Hamilton syringe needle, after which the system is back-filled using demi water.

2. The rat is deeply anesthetized with inhalation anesthesia using a mixture of $\mathrm{O}_{2}$ (0.2 L/min) and medicinal air ( $0.4 \mathrm{~L} / \mathrm{min})$ containing $1.6 \%$ isoflurane.

3. The fur on the skull is shaved and the skin surface is cleaned with $70 \%$ ethanol.

4. The animal is placed in a stereotactic frame and fixed by ear and tooth bars.

5. A skin incision is made and lidocaine is topically applied to obtain additional local anesthesia.

6. Stereotactic coordinates for intraparenchymal injection are obtained from Paxinos and Watson (see Note 12).

7. A dental drill is used to drill a small hole in the skull at the intended coordinates.

8. Prior to the injection of the vectors the meninges are punctured with a sharp 30G needle in order to prevent brain contusion during lowing of the injection needle in the brain parenchyma.

9. A pressure injection of $1 \mu \mathrm{L} r A A V$ is performed by lowering a glass needle connected to an automatic microinjection device through the hole in the skull to the appropriate depth. The microinjection device is turned on and the vector is injected at a speed of 0.1- $0.2 \mu \mathrm{L} / \mathrm{min}$.

10. After the injection the needle is left in place for 3 minutes to prevent back-flow of the viral vector solution.

11. Subsequently the needle is gently retracted and the skin is sutured. Peroperative, the animal is kept on a heating pad and an injection of fynadine is administered to obtain adequate analgesia during recovery. 
12. If an injectable anesthetic is used the animal should be left on a heating pad for 2 to 3 hours to recover.

3.7 Delivery of rAAV to the retina - intravitreal injections (in some jurisdictions this procedure needs to be performed in a suitable biosafety cabinet)

1. A sterile pulled glass micropipette (with a relatively shallow profile, tip about $200-300 \mu \mathrm{m}$ ) of known internal diameter (to readily establish volume of injection) is attached via mineral oil filled polyethylene tubing to a $50 \mu$ l Hamilton syringe (preferably via PTFE Luer Lock and a cannula with appropriate size to fit the inner diameter of the polyethylene tubing).

2. Mark the micropipette at the point where the inner total volume from the tip equals the desired volume to be injected. Then aspirate up the rAAV to the mark on the pipette.

3. Under gas/injectable anesthesia, the micropipette is inserted in the peripheral part of an animals' eye (usually via a lower temporal approach), immediately adjacent to the ora serrata. The tip should be angled towards the vitreous humor and back of the eye, taking care to avoid any damage to the retina or lens. For one injection in adult rat, the volume is usually $4 \mu \mathrm{l}$, in mice the volume is lower (1-1.5 $\mu$ l). Occasionally multiple injections into the vitreal chamber are made (e.g. a volume $1.5 \mu \mathrm{l}$ for each of three injections), to increase the area of transduction but also if different color reporter proteins are used in an attempt to examine the visual topography of retinal projections (see Note 13$)^{18}$. Inject the AAV vector into the vitreal chamber as slowly as possible. 
4. Remove the micropipette from the eye and apply eye ointment with antibiotics as preventive care.

5. Subretinal injections of AAV are also used when there is a need to target outer retina (e.g. photoreceptors). The reader is directed to Qi et al. and Muhlfriedel et al for further information and useful guidelines ${ }^{19,20}$.

\section{Notes}

1. Primers for the transgene or the promoter can be used. In most of our rAAV vectors the Woodchuck Hepatitis Virus Posttranscriptional Regulatory Element (WPRE) is present and we therefore often use primers against the WPRE, which allows for reliable intraand inter-experimental comparison of titers of different stocks.

2. We typically use 8 plates for a single batch of rAAV and this usually results in a batch with a titer between $5 \times 10^{12}$ and $2 \times 10^{13}$. We also have successfully prepared batches of rAAV with similar titers starting with 4 or 12 plates.

3. The viability of the HEK293T cells at the start of the experiment and following the transfection is critical to get high titer stocks. HEK293T cells should be evenly spread across the plate, and without visible cell clumps, for good transfection. This can be achieved by gentle, but thorough, pipetting of the cell suspension prior to plating. The cells should be growing well (typically requiring 1:10 splits every 3 days). If growth has slowed a new batch of cells should be started.

4. Mix by inversion. DNasel is somewhat fragile and should not be vortexed. 
5. The Pasteur pipette is placed through the neck of the tube and rests on the bottom. The cell lysate and iodixanol layers are then added sequentially from the bottom of the tube.

6. Arrange the tubes of iodixanol with lids off for quick access, in ascending order of concentration. After the first iodixanol solution has been added (15\%) the next one should be applied to the top of the Pasteur pipette just as the last of the previous solution enters the neck of the pipette, to minimize the possibility of air entering between the two solutions as they pass through. It often happens that some air is also transferred, resulting in small bubbles. In theory these may disturb the gradient but in practice it appears fairly robust to such disturbances. However there is limited time to load the next solution in the serological pipette. It is advisable therefore not to change the serological pipette between solutions.

7. A few small bubbles invariably remain. This should not cause problems.

8. Experienced virus purifiers may prefer to hold the Beckman tube in one hand and insert the needles with the other rather than using a stand and clamp.

9. DPBS can be used instead of DPBS-sucrose for the first 3 washes.

10. In general AAV particles are robust to freeze-thawing and we prefer not to make more than 2-3 aliquots. It is advisable not to make small aliquots as this can reduce titre.

11. The final $\mathrm{pH}$ is important for the subsequent $\mathrm{qPCR}$ and should be ideally around 8 . We recommend preparing additional tubes with only D-PBS and $1 \mathrm{M} \mathrm{NaOH}$ and then checking the exact volume of neutralization solution required to return the $\mathrm{pH}$ to 7-8.5. Check with $\mathrm{pH}$ paper or indicator solution. Use the same pipette as you will for the samples. 
12. Optimization of the stereotactic coordinates to be used for a particular brain structure includes the injection of a dye, e.g. fast green or methylene blue, and serial sectioning of the brain through the injection area ${ }^{15}$.

13. Some researchers remove a small volume of vitreous just prior to the intravitreal AAV injection.

\section{Acknowledgement}

We acknowledge the support of the International Spinal Research Trust (STR 111), a ZonMW TOP grant, and the ZonMW dementia research and innovation program Memorabel (grant nr. 733050106) for financial support.

\section{References}

1. Murlidharan G, Samulski RJ, Asokan A (2014) Biology of adeno-associated viral vectors in the central nervous system. Front Mol Neurosci 7:76.

2. Xiao X, Li J, Samulski RJ (1998) Production of high-titer recombinant adeno-associated virus vectors in the absence of helper adenovirus. J Virol 72:2224-2232.

3. Grimm D, Kay MA, Kleinschmidt JA (2003) Helper virus-free, optically controllable, and twoplasmid-based production of adeno-associated virus vectors of serotypes 1 to 6 . Mol Ther 7:839-850.

4. Zolotukhin S, Potter M, Zolotukhin I et al (2002) Production and purification of serotype 1, 2, and 5 recombinant adeno-associated viral vectors. Methods 28:158-167.

5. Grimm D, Kern A, Rittner, K et al (1998) Novel tools for production and purification of recombinant adenoassociated virus vectors. Hum Gene Ther 9:2745-2760. 
6. Gao GP, Alvira MR, Wang L et al (2002) Novel adeno-associated viruses from rhesus monkeys as vectors for human gene therapy. Proc Natl Acad Sci U S A 99:11854-11859.

7. Mietzsch M, Grasse S, Zurawski C et al (2014) OneBac: platform for scalable and high-titer production of adeno-associated virus serotype 1-12 vectors for gene therapy. Hum Gene Ther 25:212-222.

8. Smith RH, Levy JR, Kotin RM (2009) A simplified baculovirus-AAV expression vector system coupled with one-step affinity purification yields high-titer rAAV stocks from insect cells. Mol Ther 17:1888-1896.

9. Grieger JC, Soltys SM, Samulski RJ (2016) Production of Recombinant Adeno-associated Virus Vectors Using Suspension HEK293 Cells and Continuous Harvest of Vector From the Culture Media for GMP FIX and FLT1 Clinical Vector. Mol Ther 24:287-297.

10. Hermens WT, et al (1999) Purification of recombinant adeno-associated virus by iodixanol gradient ultracentrifugation allows rapid and reproducible preparation of vector stocks for gene transfer in the nervous system. Hum Gene Ther 10:1885-1891.

11. Zolotukhin S, Byrne BJ, Mason E et al (1999) Recombinant adeno-associated virus purification using novel methods improves infectious titer and yield. Gene Ther 6:973-985.

12. Blits B, Derks S, Twisk J et al (2010) Adeno-associated viral vector (AAV)-mediated gene transfer in the red nucleus of the adult rat brain: comparative analysis of the transduction properties of seven AAV serotypes and lentiviral vectors. J Neurosci Methods 185:257-263.

13. Drummond ES, Muhling J, Martins RN et al (2013) Pathology associated with AAV mediated expression of beta amyloid or C100 in adult mouse hippocampus and cerebellum. PLoS One 8:e59166.

14. Ruitenberg MJ, Blits B, Dijkhuizen PA et al (2004) Adeno-associated viral vector-mediated gene transfer of brain-derived neurotrophic factor reverses atrophy of rubrospinal neurons following both acute and chronic spinal cord injury. Neurobiol Dis 15:394-406. 
15. Ruitenberg, MJ, Eggers R, Boer, GJ et al (2002) Adeno-associated viral vectors as agents for gene delivery: application in disorders and trauma of the central nervous system. Methods 28:182-194.

16. Harvey AR, Kamphuis W, Eggers R et al (2002) Intravitreal injection of adeno-associated viral vectors results in the transduction of different types of retinal neurons in neonatal and adult rats: a comparison with lentiviral vectors. Mol Cell Neurosci 21:141-157.

17. Hellstrom M, Ruitenberg MJ, Pollett MA et al (2009) Cellular tropism and transduction properties of seven adeno-associated viral vector serotypes in adult retina after intravitreal injection. Gene Ther 16:521-532.

18. You SW, Hellström M, Pollett MA et al (2016) Large-scale reconstitution of a retina-to-brain pathway in adult rats using gene therapy and bridging grafts: An anatomical and behavioral analysis. Exp Neurol 279:197-211.

19. Muhlfriedel R, Michalakis S, Garcia Garrido M et al (2013) Optimized technique for subretinal injections in mice. Methods Mol Biol 935:343-349.

20. Qi Y, Dai X, Zhang H et al (2015) Trans-Corneal Subretinal Injection in Mice and Its Effect on the Function and Morphology of the Retina. PLoS One 10:e0136523.

\section{Figure legends:}

Fig 1. Illustration of a Beckman Quick seal ultracentrifuge tube and the Pasteur pipet lowered through the neck of the tube to generate the graded iodixanol gradient. We refer to Section 3.3 of the protocol for a more detailed description of the procedure to load the crude lysate and create the gradient. 


\begin{tabular}{|c|c|c|}
\hline Serotype & Helper plasmid & Reference \\
\hline AAV 1 & helper plasmid: PVD20 & Grimm et al $2003^{3}$ \\
\hline AAV 2 & helper plasmid: pDG2 & Grimm et al $1998^{5}$ \\
\hline AAV 3 & helper plasmid: pXR3m1.m2 & Grimm et al $2003^{3}$ \\
\hline AAV 4 & helper plasmid: pXR4m1.m2 & Grimm et al $2003^{3}$ \\
\hline AAV 5 & helper plasmid: pDP5 & Grimm et al $2003^{3}$ \\
\hline AAV 6 & helper plasmid: pDP6 & Grimm et al $2003^{3}$ \\
\hline \multirow[t]{2}{*}{ AAV 7} & helper plasmid 1: p5E18DV2/7 & Gao et al $2002^{6}$ \\
\hline & helper plasmid 2: $\mathrm{pAd} \Delta \mathrm{F} 6$ & Gao et al $2002^{6}$ \\
\hline \multirow[t]{2}{*}{ AAV 8} & helper plasmid 1: p5E18DV2/8 & Gao et al $2002^{6}$ \\
\hline & helper plasmid 2: pAd $\Delta \mathrm{F} 6$ & Gao et al $2002^{6}$ \\
\hline \multirow[t]{2}{*}{ AAV 9} & helper plasmid 1: pAAV2/9 & Vector Core University of Pennsylvania \\
\hline & helper plasmid 2: pAd $\Delta \mathrm{F} 6$ & Gao et al $2002^{6}$ \\
\hline
\end{tabular}


Table 2. Preparation of PEI transfection solutions

Two plasmid system (AAV serotypes 1 to 6)

\begin{tabular}{l|l|l}
\hline Solution (A) & Per $15 \mathrm{~cm}$ plate & 8 plates \\
\hline $\mathrm{PEl}$ & $150 \mu \mathrm{L}$ & $1200 \mu \mathrm{L}$ \\
$\mathrm{NaCl}$ & To $1.5 \mathrm{~mL}$ & To $12 \mathrm{~mL}$ \\
\hline \multicolumn{3}{|l}{} \\
\hline Solution (B) & Per $15 \mathrm{~cm}$ plate & 8 plates \\
\hline Helper plasmid & $37.5 \mu \mathrm{g}$ & $300 \mu \mathrm{g}$ \\
Transfer plasmid & $12.5 \mu \mathrm{g}$ & $100 \mu \mathrm{g}$ \\
$\mathrm{NaCl}$ & To $1.5 \mathrm{~mL}$ & To $12 \mathrm{~mL}$ \\
\hline
\end{tabular}

Three plasmid system (AAV serotypes 7 to 9)

\begin{tabular}{l|l|l}
\hline Solution $(A)$ & Per $15 \mathrm{~cm}$ plate & 8 plates \\
\hline PEl & $150 \mu \mathrm{L}$ & $1200 \mu \mathrm{L}$ \\
$\mathrm{NaCl}$ & To $1.5 \mathrm{~mL}$ & To $12 \mathrm{~mL}$ \\
\hline \hline Solution (B) & Per $15 \mathrm{~cm}$ plate & 8 plates \\
\hline Helper plasmid 1 & $25 \mu \mathrm{g}$ & $200 \mu \mathrm{g}$ \\
Helper plasmid 2 & $25 \mu \mathrm{g}$ & $200 \mu \mathrm{g}$ \\
Transfer plasmid & $12.5 \mu \mathrm{g}$ & $100 \mu \mathrm{g}$ \\
$\mathrm{NaCl}$ & To $1.5 \mathrm{~mL}$ & To $12 \mathrm{~mL}$ \\
\hline
\end{tabular}

